\section{REFERENCES}

1. Galimov OV, Khanov VO, Rylova TV, et al. Endoskopicheskiye vmeshatel'stva pri polipakh zheludka [Endoscopic treatment of gastric polips]. Khirurgiya; Zhurnal imeni NI Pirogova [Surgery; Magazine them NI Pirogov]. 2009; 1: 20-24.

2. Dinis-Ribeiro M, Castro R, Libânio D, Pita I. Solutions for submucosal injection: what to choose and how to do it. World Journal of Gastroenterology. 2019; 25 (7): 777-788. DOI: 10.3748/wjg.v25.i7.777

3. Il'kanich AYa, Barbashinov NA. Opyt lecheniya bol'nykh s polipami i polipoznymi obrazovaniyami tolstoy kishki [Experience in the treatment of patients with polyps and polyposis of the colon]. V sbornike: fundamental'nyye i prikladnyye problemy zdorov'yesberezheniya cheloveka na severe; Sbornik materialov II Vserossiyskoy nauchnoprakticheskoy konferentsii [In the collection: fundamental and applied problems of human health in the north; Collection of materials of the II All-Russian scientificpractical conference]. 2017; 298-301.

4. Katina EL, Konorev MR. Prognosticheskiye faktory povtornogo obrazovaniya polipov zheludka posle provedeniya endoskopicheskoy polipektomii [Prognostic factors for the re-formation of polyps of the stomach after endoscopic polypectomy]. Vestnik VGMU [Bulletin of Vitebsk State Medical University.] 2015; 14 (5): 57-64.

5. Ferlitsch M, Waldmann E, Jeschek P, Penz D, et al. Colorectal polypectomy and endoscopic mucosal resection (emr): european society of gastrointestinal endoscopy (esge) clinical guideline. Endoscopy. 2017; 49 (3): 270297. DOI: $10.1055 / \mathrm{s}-0043-102569$

6. Kanishchev YuV, Samgina TA, Bushueva OYu, Nazarenko PM, Polonikov AV. Endoskopicheskaya polipektomiya pri mnozhestvennykh polipakh zheludka s pomoshch'yu lazera [Endoscopic polypectomy with multiple polyps of the stomach using a laser]. V sbornike: Mediko-biologicheskiye aspekty mul'tifaktorial'noy patologii [In the collection: Medical and biological aspects of multifactorial pathology]. 2016; 56-57.

7. Lukashevich TA, Zaprudsky KS, Antiperovich OF. Polipoz tolstogo kishechnika; Sovremennyye podkhody k diagnostike i lecheniyu [Polyposis of the large intestine; Modern approaches to diagnosis and treatment]. $\mathrm{V}$ sbornike: Innovatsii v meditsine i farmatsii - 2018; Sbornik materialov distantsionnoy nauchno-prakticheskoy konferentsii studentov i molodykh uchenykh; Minsk: Belorusskiy gosudarstvennyy meditsinskiy universitet [In the collection: Innovations in Medicine and Pharmacy 2018; Collection of materials of the distance scientificpractical conference of students and young scientists; Minsk: Belarusian State Medical University]. 2018; 21-25.

8. Sethi A, Wong Kee Song LM. Adverse events related to colonic endoscopic mucosal resection and polypectomy. Gastrointestinal Endoscopy Clinics of North America. 2015; 25 (1): 56-69. DOI: 10.1016/j.giec.2014.09.007

9. Boltrukevich PG. Chastota vozniknoveniya polipov tolstoy kishki v zavisimosti ot topografo-anatomicheskogo stroyeniya razlichnykh yeye otdelov [The frequency of occurrence of colon polyps, depending on the topographic and anatomical structure of its various departments]. Smolenskiy meditsinskiy al'manakh [Smolensk medical almanac]. 2016; 1: 38-41.

10. Fokin YuN, Shklovsky BL, Tatarin VS, Savvin VYu, Baksheev VI. Polipy zheludka kak predrak: opyt lechebnodiagnosticheskoy taktiki $\vee$ mnogoprofil'nom statsionare [Gastric polyps as a precancer: the experience of treatment and diagnostic tactics in a multidisciplinary hospital]. Voyenno-meditsinskiy zhurnal [Military Medical Journal]. 2019; 340 (7): 36-44.

11. Kudryavtsev LP, Veliev MT, Degtyarenko SA, Nedoruba EA. Primeneniye tekhnologii uzkospektral'noy vizualizatsii pri endoskopicheskikh polipektomiyakh tolstoy kishki [Application of narrow-spectral imaging technology for endoscopic polypectomy of the colon]. Molodoy uchenyy [Young scientist]. 2016; 23 (127): 154-156.

12. Nedoluzhko IYu, Kazakova SS, Chernikova EN, Shishin KV, Kurushkina NA. Osobennosti perioperatsionnogo perioda pri endoskopicheskoy polipektomii i rezektsii slizistoy tolstoy kishki u patsiyentov pozhilogo i starcheskogo vozrasta [Features of the perioperative period with endoscopic polypectomy and resection of the colon mucosa in elderly and senile patients]. Doktor Ru [Doctor Ru]. 2015; 2 (103): 44.

13. Anderloni A, Jovani M, Hassan C, Repici A. Advances, problems, and complications of polypectomy. Clinical and Experimental Gastroenterology. 2014; 7 (1): 285-296. DOI: $10.2147 / C E G . S 43084$

\title{
THE IMPACT OF PSYCHO-EMOTIONAL TENSION IN CHILDREN DURING A DENTAL INTERVENTION ON THE DISTRESS DEVELOPMENT IN DENTISTS
}

KAZAKOVA LARISA N., ORCID ID: 0000-0001-8060-1348; C. Med. Sci., associate professor of the Department of pediatric dentistry and orthodontics of Saratov State Medical University n.a. V.I. Razumovsky, Russia, Saratov, 410012, B. Kazachya str., 112, tel. 8-905-321-06-11, e-mail: avkuligin@yandex.ru

FIRSOVA IRINA V., C. Med. Sci., associate professor of the Department of pediatric dentistry and orthodontics of Saratov State Medical University n.a. V.I. Razumovsky, Russia, 410012, Saratov, B. Kazachya str., 112, tel. 8-937-966-70-72,

e-mail: suetenkov@gmail.com

DAVYDOVA NATALIYA V., assistant of professor of the Department of pediatric dentistry and orthodontics of Saratov State Medical University n.a. V.I. Razumovsky, Russia, 410012, Saratov, B. Kazachya str., 112, tel. 8-903-386-30-12, e-mail:natdav13@yandex.ru

MAKHONOVA EKATERINA V., assistant of professor of the Department of pediatric dentistry and orthodontics of Saratov State Medical University n.a. V.I. Razumovsky, Russia, 410012, Saratov, B. Kazachya str., 112, tel. 8-917-210-24-09, e-mail: mahonova.ev@mail.ru

NARYZHNAYA ELENA V., assistant of professor of the Department of pediatric dentistry and orthodontics of Saratov State Medical University n.a. V.I. Razumovsky, Russia, 410012, Saratov, B. Kazachya str., 112, tel. 8-905-384-40-03, e-mail: eturusova@bk.ru 
SAYUTINA LARISA V., resident of the Department of pediatric dentistry and orthodontics of Saratov State Medical University n.a. V.I. Razumovsky, Russia, 410012, Saratov, B. Kazachya str., 112, tel. 8-905-384-40-03, e-mail: larisochka00@rambler.ru

Abstract. The professional activity of a dentist is subject to many stress factors in rendering quality medical care to children. The increased level of psycho-emotional tension in children cannot but affect the emotional state of the dentist. In turn, accumulation of psychological tension leads to moral and physical exhaustion of the doctor. Aim. The aim of the study is to characterize the stress resistance in pediatric dentists working in practical health care during active labor activity, to identify symptoms of psycho-emotional tension and its impact on cardiovascular system indicators. Material and methods. A group of 30 doctors was examined, with a mean age of 38 years and an average duration of service of 14 years. In the course of the study they conducted a survey using the Akioshi Kitaioka method and monitored cardiovascular system activity during the working week. Conclusion. Low stress resistance in practicing pediatric dentists, does not provide optimal adaptation of the body in extreme conditions, which is confirmed by increasing fatigue, exhaustion, reduced attention levels, reduced ability to concentrate at the end of the work shift and of the working week. Prolonged negative emotional stress leads to the development of distress in practicing pediatric dentists, which is confirmed by insufficient functionality of the cardiovascular system.

Key words: pediatric dentist, stress resistance, psycho emotional tension, stress, distress.

For reference: Kazakova LN, Firsova IV, Davydova NV, Makhonova EV, Naryzhnaya EV, Sayutina LV. The impact of psycho-emotional tension in children during a dental intervention on the distress development in dentists. The Bulletin of Contemporary Clinical Medicine. 2020; 13 (2): 41-45. DOI: 10.20969/VSKM.2020.13(2).41-45.

\title{
ВЛИЯНИЕ ПСИХОЭМОЦИОНАЛЬНОГО НАПРЯЖЕНИЯ ДЕТЕЙ ВО ВРЕМЯ СТОМАТОЛОГИЧЕСКОГО ВМЕШАТЕЛЬСТВА НА ФОРМИРОВАНИЕ ДИСТРЕССА У СТОМАТОЛОГОВ
}

КАЗАКОВА ЛАРИСА НИКОЛАEBHA, ORCID ID: 0000-0001-8060-1348; канд. мед. наук, доцент кафедры стоматологии детского возраста и ортодонтии ФГБОУ ВО “Саратовский ГМУ им. В.И. Разумовского» Минздрава России, Россия, 410012, Саратов, ул. Б. Казачья, 112, тел. 8-905-321-06-11, e-mail: avkuligin@yandex.ru

ФИРСОВА ИРИНА ВЛАДИМИРОВНА, канд. мед. наук, доцент кафедры стоматологии детского возраста и ортодонтии ФГБОУ ВО «Саратовский ГМУ им. В.И. Разумовского» Минздрава России, Россия, 410012, Саратов, ул. Б. Казачья, 112 , тел. 8-937-966-70-72, e-mail: suetenkov@gmail.com

ДАВЫДОВА НАТАЛИЯ ВЛАДИМИРОВНА, асСИстент кафедры стоматологии детского возраста и ортодонтии ФГБОУ ВО «Саратовский ГМУ им. В.И. Разумовского» Минздрава России, Россия, 410012, Саратов, ул. Б. Казачья, 112, тел. 8-903-386-30-12, e-mail: natdav13@yandex.ru

МАХОНОВА ЕКАТЕРИНА ВЛАДИМИРОВНА, асСИстент кафедры стоматологии детского возраста и ортодонтии ФГБОУ ВО «Саратовский ГМУ им. В.И. Разумовского» Минздрава России, Россия, 410012, Саратов, ул. Б. Казачья, 112, тел. 8-917-210-24-09, e-mail: mahonova.ev@mail.ru

НАРЫЖНАЯ ЕЛЕНА ВЛАДИМИРОВНА, асСИСтеНт Кафедры Стоматологии детского возраста и ортодонтии ФГБОУ ВО «Саратовский ГМУ им. В.И. Разумовского» Минздрава России, Россия, 410012, Саратов, ул. Б. Казачья, 112, тел. 8-905-384-40-03, e-mail: eturusova@bk.ru

САЮТИНА ЛАРИСА ВЛАДИМИРОВНА, ординатор кафедры стоматологии детского возраста и ортодонтии ФГБОУ ВО «Саратовский ГМУ им. В.И. Разумовского» Минздрава России, Россия, 410012, Саратов, ул. Б. Казачья, 112, тел. 8-905-384-33-03, e-mail: larisayutina96@yandex.ru

\begin{abstract}
Реферат. Профессиональная деятельность врача-стоматолога подвержена множеству стрессовых факторов при оказании качественной медицинской помощи детскому населению. Повышенный уровень психоэмоционального напряжения детей не может не отразиться на эмоциональном состоянии врача-стоматолога. В свою очередь, накопление психологического напряжения ведет к моральному и фризическому истощению врача. Цель исследования - охарактеризовать стрессоустойчивость детских врачей-стоматологов, работающих в практическом здравоохранении в период активной трудовой деятельности, выявить симптомы психоэмоционального напряжения и его влияние на показатели сердечно-сосудистой системы. Материал и методы. Была обследована группа врачей в количестве 30 человек, средний возраст которых составлял 38 лет, средний стаж работы - 14 лет. В процессе исследования проводили анкетирование по методике Акиоши Китаока и мониторинг деятельности сердечно-сосудистой системы в течение рабочей недели. Результаты и их обсуждение. Анализ полученных результатов при анкетировании показал значительное влияние профессиональной деятельности детских врачей-стоматологов на уровень психического здоровья, которое оказывало непосредственное влияние на общее состояние организма, включая сердечно-сосудистую систему. Выводы. Низкая стрессустойчивость практикующих детских стоматологов не обеспечивает оптимальную адаптацию организма в экстремальных условиях, что подтверждается нарастающей утомляемостью, усталостью, снижением уровня внимания, снижением способности концентрироваться в конце рабочей смены и рабочей недели. Длительно действующая отрицательная эмоциональная нагрузка приводит к развитию дистресса у практикующих детских стоматологов, что подтверждается недостаточностью функциональных возможностей сердечно-сосудистой системы.

Ключевые слова: врач-стоматолог детский, стрессоустойчивость, психоэмоциональное напряжение, стресс, дистресс.

Для ссылки: Влияние психоэмоционального напряжения детей во время стоматологического вмешательства на формирование дистресса у стоматологов / Л.Н. Казакова, И.В. Фирсова, Н.В. Давыдова [и др.] // Вестник современной клинической медицины. - 2020. - Т. 13, вып. 2. - С.41-45. DOI: 10.20969/VSKM.2020.13(2).41-45.
\end{abstract}


ntroduction. Avicenna wrote about the importance

of the stage of establishing and maintaining contact between the patients and doctors of any profession: «If I do find the paths to people hearts, they will not communicate with me, although they will not be for or against me» $[1,2]$.

The relevance of this in pediatric dentistry does not decrease even nowadays, despite the modern achievements in science, and this is due primarily to the human factor, the skills, proficiency, and professionalism of the doctor.

The work of a pediatric dentist is characterized both by physical exertion and by daily emotionally intense interaction with patients and their representatives [3, $4,5]$. This is primarily due to the fear experienced by children in all age groups, during all dental interventions. Doctors of all specializations face the need to restore the comfortable psycho-emotional state of the patient, regardless of the age of the patient. To prevent the development of complications against the background of acute stress, which often develops in children with expressed psycho emotional stress and to find a possible and suitable method of anesthesia in the the course of dental care delivery are the main tasks at the first stage of interaction, which doctors face daily and repeatedly during their work. It is only possible to correctly assess the clinical situation, to choose and to conduct a quality treatment if the first stage was successful $[6,7]$.

For most dentists, intense emotional stress during the inadequate behavior of children and their representatives and the need to consistently adhere to a calm tone of speaking is one of the main characteristics of the working environment. Interaction with irritating, toxic substances that contribute to sensitization of the body and to development of allergies, the risk of infection, forced working posture, burdened by static loads and a long-time vibration, further strengthen the negative impact of professional activity on the health of a doctor. The behavior of a dentist is determined by a combination of social norms, he/she must be competent, restrained, patient, and attentive in any circumstances.

Surveys of Russian doctors have shown that the need for constant contact with patients and their relatives plays a leading role in chronic emotional stress development in $33,8 \%$ of pediatricians, $37,5 \%$ of dermatologists, $45,2 \%$ of neurologists and $68,7 \%$ of psychiatrists $[2,8]$.

The most common diseases in practicing physicians are, according to the literature, borderline neuropsychiatric disorders, diseases of the cardiovascular system, the musculoskeletal system and peripheral nervous system disorders.

Aim of the study. To characterize the stress resistance of pediatric dentists working in the public health system during their active working period and to identify the symptoms of psychoemotional stress and its effect on the cardiovascular system.

Methods. The study included a questionnaire survey and monitoring of cardiovascular system activity of a group of 30 dentists with an average age of 38 years and an average work experience of 14 years. In the process of the survey, a questionnaire was conducted and the activity of the cardiovascular system was monitored during the working week. The questionnaire was used to determine the psychoemotional and physical condition of pediatric dentists before and after the study.

During the workweek, two times per day - before and after work - tests were performed to determine the psychoemotional state of pediatric dentists, as well as the state of the cardiovascular system: blood pressure (systolic and diastolic), the pulse rate, and the Robinson index were determined and evaluated. During the weekend, the patients performed the monitoring of the cardiovascular system indicators themselves and the indicators were included in the general table.

In the survey, the respondents by themselves characterized the state of their mental and physical health at the time of the study. Questionnaires for assessing the mental and physical state were developed on the basis of studies conducted by V. Boyko [3].

Using this method of testing, we systematically assessed the mental state of doctors according to the method of Akiyoshi Kitaoka. Kitaoka's methodology helps to understand the mental state of a person and how he feels at the time of the study. Kitaoka proposed to analysethe mental state of the patients with various pictures - illusions created with the help of modern computer technologies. It is enough to just look at the picture and express your feelings at that moment.

1) if the drawings are absolutely still - you do not have to worry about anything, your mental health is in perfect order;

2) if the pictures move slowly - you need to rest, both physically and morally;

3 ) active movement of the pattern may serve as a symptom of:

- accumulated fatigue;

- high level of stress experienced at the moment;

- deterioration of health.

Results and discussion. Analysis of the results obtained during the questionnaires showed a significant influence of the professional activity of pediatric dentists on the level of mental health (Table 1). Fast fatigue, insomnia, frequent mood changes, headaches for no apparent reason were frequent complaints from the study participants. During the working week, such indicators as fatigue, irritability, negative emotional attitude towards the performed activity increased, especially when interacting with patients with a pronounced level of psychoemotional stress. Analysis of the results of the testsusing Kitaoka's methodology showed a pronounced influence of the behavioral reactions of children, characterized by a pronounced emotional reaction, on the psychosomatic state of the doctors. It was noted that, during the working week, significant changes of the cardiovascular system were always accompanied by expressed psychoemotional reactionsin the study group $[9,10]$.

Monitoring of cardiac activity showed an increase inblood pressure, heart rate, and mean arterial pressure during the working week for all participants (Table 2). Significant disorders of the cardiovascular system were detected at the beginning of the work week in $10 \%$ of the surveyed and in $40 \%$ of the surveyedat the end of the work week. The high values of the Robinson 
Characteristics of psychoemotional and physical condition of doctors at the time of study

Та блиц а 1

Характеристика психоэмоционального и физического состояния врачей на момент исследования

\begin{tabular}{|c|c|c|}
\hline \multirow{2}{*}{$\begin{array}{l}\text { Characteristics of the general state of the respondents } \\
\text { (mental and physical) }\end{array}$} & \multicolumn{2}{|c|}{$\begin{array}{l}\text { The personal assessment of respondents } \\
\text { (quantity) }\end{array}$} \\
\hline & $\begin{array}{c}\text { Associated with } \\
\text { professional activities }\end{array}$ & $\begin{array}{l}\text { Not related to } \\
\text { professional activities }\end{array}$ \\
\hline 1. You often experience fatigue, fatigue, exhaustion (after active professional activity) & 30 people & - \\
\hline 2. You complain about frequent changes of mood, emotional lability & 30 people & - \\
\hline $\begin{array}{l}\text { 3. Psychosomatic problems are common (fluctuations in blood pressure, headaches, } \\
\text { diseases of the gastrointestinal tract and cardiovascular system, neurological } \\
\text { disorders) }\end{array}$ & 27 people & 3 \\
\hline 4. You suffer from sleep disorders & 22 people & 8 \\
\hline $\begin{array}{l}\text { 5. Do you often have a negative attitude towards people (after having positive } \\
\text { relationships)? }\end{array}$ & 27 people & 3 \\
\hline $\begin{array}{l}\text { 6. Do you often experience a negative emotional attitude toward the professional } \\
\text { activity (instead of «it's my calling in life» attitude of before) }\end{array}$ & 26 people & 4 \\
\hline $\begin{array}{l}\text { 7. For you, the following is typical: stereotyping of personal attitude, standardization } \\
\text { of communication and activities, adoption of ready-made forms of knowledge, } \\
\text { narrowing of the repertoire of work actions, rigidity of thought operations }\end{array}$ & 29 people & 1 \\
\hline $\begin{array}{l}\text { 8. Do you observe the intensification of aggressive tendencies (anger and irritability } \\
\text { towards other people) }\end{array}$ & 30 people & \\
\hline $\begin{array}{l}\text { 9. Over the course of time, a negative attitude towards yourself has become } \\
\text { characteristic }\end{array}$ & 24 people & 6 \\
\hline $\begin{array}{l}\text { 10. You often experience anxious state, accompanied by negative emotional } \\
\text { experiences }\end{array}$ & 28 people & 2 \\
\hline $\begin{array}{l}\text { 11. In the course of labor activity over years, pessimistic attitudes and depression } \\
\text { increase }\end{array}$ & 28 people & 2 \\
\hline 12. Do you often feel guilty before the patients in the process of work? & 30 people & - \\
\hline
\end{tabular}

Table 2

Average values of the indicators of the cardiovascular system $(\mathrm{M} \pm \mathrm{m}, n=30)$ and indices of the level of psychoemotional tension by the method of Kitaoka

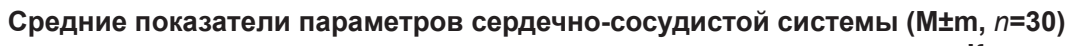
и показатели уровня психоэмоционального напряжения по методике Китоака

\begin{tabular}{|c|c|c|c|c|c|c|c|c|c|c|c|c|}
\hline \multirow{3}{*}{$\begin{array}{l}\text { Day } \\
\text { of the } \\
\text { week }\end{array}$} & \multirow{2}{*}{\multicolumn{2}{|c|}{$\begin{array}{l}\text { Kitaokamet } \\
\text { hod }\end{array}$}} & \multirow{2}{*}{\multicolumn{2}{|c|}{ Heartrate }} & \multicolumn{6}{|c|}{ Blood pressure } & \multirow{2}{*}{\multicolumn{2}{|c|}{ Robinson index }} \\
\hline & & & & & \multicolumn{2}{|c|}{ Systolic } & \multicolumn{2}{|c|}{ Diastolic } & \multicolumn{2}{|c|}{ Average } & & \\
\hline & before & after & before & after & before & after & before & after & before & after & before & after \\
\hline 1 & 1,6 & 2,2 & $84,3 \pm 2,5$ & $85,7 \pm 2,7$ & $121,1 \pm 1,6$ & $129,0 \pm 2,2$ & $76,2 \pm 1,6$ & $86,4 \pm 2,8$ & $91,2 \pm 1,5$ & $100,8 \pm 2,6$ & $102 \pm 2,1$ & $110,5 \pm 4,1$ \\
\hline 2 & 1,8 & 2,4 & $81,7 \pm 1,8$ & $85,2 \pm 2,4$ & $123,2 \pm 3,4$ & $138,5 \pm 1,6$ & $80,2 \pm 1,8$ & $86,2 \pm 3,2$ & $94,5 \pm$ & $103,6 \pm$ & $100,5 \pm 1,2$ & $118,2 \pm 1,4$ \\
\hline 3 & 1,8 & 2,6 & $82,5 \pm 2,4$ & $86,4 \pm 3,2$ & $132,2 \pm 2,2$ & $144,2 \pm 1,8$ & $86,5 \pm 2,4$ & $89,2 \pm 1,8$ & $101,7 \pm 1,8$ & $107,5 \pm 2,6$ & $109,2 \pm 1,2$ & $124,6 \pm$ \\
\hline 4 & 1,8 & 2,8 & $78,2 \pm 2,6$ & $88,4 \pm 1,2$ & $130,4 \pm 3,6$ & $148,4 \pm 2,8$ & $82,2 \pm 1,6$ & $86,4 \pm 4,4$ & $98,3 \pm 2,2$ & $107 \pm 1,8$ & $102 \pm 1,4$ & $131,2 \pm 1,2$ \\
\hline 5 & 2,4 & 2,8 & $80,4 \pm 3,2$ & $90,2 \pm 4,4$ & $138,6 \pm 2,4$ & $154,6 \pm 4,6$ & $85,2 \pm 4,4$ & $96,4 \pm 3,6$ & $103 \pm 2,6$ & $115,8 \pm 4,4$ & $109,2 \pm 1,6$ & $139,4 \pm 1,2$ \\
\hline 6 & 2,4 & 2,2 & $84,4 \pm 3,6$ & $88,8 \pm 3,8$ & $135,8 \pm 4,4$ & $156,4 \pm 2,4$ & $84,4 \pm 2,8$ & $98,8 \pm 4,6$ & $101,5 \pm 3,2$ & $117,8 \pm 4,8$ & $114,6 \pm 1,4$ & $138,9 \pm 2,2$ \\
\hline 7 & 1,8 & 1,8 & $75,2 \pm 1,2$ & $80,2 \pm 1,4$ & $120,4 \pm 2,2$ & $126,2 \pm 2,4$ & $78,8 \pm 1,2$ & $82,4 \pm 2,2$ & $92,7 \pm 1,2$ & $97 \pm 1,2$ & $90,5 \pm 1,6$ & $101,2 \pm$ \\
\hline$p$ & & & \multicolumn{2}{|c|}{$>0,5$} & \multicolumn{2}{|c|}{$<0,01$} & \multicolumn{2}{|c|}{$<0,01$} & \multicolumn{2}{|c|}{$<0,01$} & \multicolumn{2}{|c|}{$<0,02$} \\
\hline
\end{tabular}

index at the end of the working day during the whole work week in the study group indicates a regulation disorder of the cardiovascular system and of its compensatory capabilitiesdisorder. During rest periods from professional activity, no significant changes for the cardiovascular system were observed. Containment of their feelings in emotionally strained communication leads to emotional exhaustion and is accompanied by pronounced changes in vegetative reactions, which is confirmed by the development of stress-induced arterial hypertension (or «hypertension in the workplace») in pediatric dentists - a characteristic feature of all occupations with high psychoemotional load.

The value of $\mathrm{P}$ is determined from the reliability table, based on the result - $\mathrm{t}-\mathrm{Student}$ :

$$
t=\frac{M 1-M 2}{\left(\mathrm{~m}_{1}^{2}+\mathrm{m}_{2}^{2}\right)^{1 \mid 2}} t=\frac{M 1-M 2}{\left(\mathrm{~m}_{1}^{2}+\mathrm{m}_{2}^{2}\right)^{1 \mid 2}},
$$

where $M$ - indicators of the cardiovascular system; $m_{1}$ и $m_{2-}$ statistical errors.

Conclusion. Low stress resistance of practicing pediatric dentists, which is a consequence of their 
professional activities,does not provide for a sufficient adaptation of the organism in extreme conditions, which is confirmed by the increasing fatigue, tiredness, a decrease in attentiveness, and a reduced ability to concentrate at the end of the working shift and workweek. Continuous negative emotional stress leads to the development of distress in pediatric dentists and is proven by the insufficient functional capabilities of their cardiovascular system.

Transparency of study. The study had no sponsorship. The authors take full responsibility for the delivery of finalized manuscript to print.

Declaration on financial and other relationships. All authors contributed to development of concept and design of study and manuscript writing. The final version of manuscript was approved by all authors. The authors received no payments for the study.

Conflict of interest. The authors declare no apparent or potential conflict of interests caused by publication of this article.

\section{LITERATURE}

1. Berezin, V. Wisdom of the millennium. Encyclopedia / V. Berezin; ed. by A. Yanak. - M.: OLMA-PRESS, 2006. $830 \mathrm{p}$.

2. Vinokurov, V.A. Professional stress among doctors / V.A. Vinokurov // Vestnik MAPO. - 2010. - № 8/9. P.104-105.

3. Vodopianova, N.E. Burnout syndrome: diagnostics and prevention / N.E. Vodopianova, E.S. Starchenkova. St. Petersburg: Piter, 2008. -56 p.

4. Boyko, V.V. Syndrome of "emotional burnout» in professional communication / V.V. Boyko. - St. Petersburg: Piter, $2004-105 \mathrm{p}$.

5. Subaev, M.N. Characteristics of professional stress among child dentists in the working environment / M.N. Subaev, N.P. Setko // Sovremennye problemy nauki i obrazovaniya. - 2015. - № 1. - P.1288.

6. Larentseva, L.I. Professional stress and syndrome of emotional burnout among dentists conducting outpatient treatment of children / L.I. Larentseva, E.A. Rvacheva // Rossiiskii stomatologicheskii zhurnal. - 2010. - № 1. P.36-37.

7. Kotova, E.V. Burnout syndrome prevention: training manual: ychebnoe posobie / E.V. Kotova. - Krasnoyarsk: Krasnoyarskii gosudarstvennii pedagogicheskii universitet imeni V.P. Astafeva, 2013 - 76 p.

8. Lozinskaya, E.I. System index of burnout syndrome (based on MBI test): methodological recommendations / E.I. Lozinskaya, N.B. Lutova. - Moscow: NIPNI n.a. Behterev, 2007. - 103 p.

9. Maslach, Ch. A multidimensional Theory of Burnout. Theories of Organizational Strees Cary / Ch. Maslach, L. Cooper. - Oxford Univercity press, 1998. - P.66-85.
10. Yudina, N.A. The rationale for pathogenic mechanisms of relationship between dental and general diseases / N.A. Yudina // Stomatologicheski Zhurnal. - 2007. № 2. - P.16-19.

\section{REFERENCES}

1. Berezin $\mathrm{V}$, Yanak A, ed. Mydroct' tysyacheletia [Wisdom of the millennium]. Moskva: OLMA-PRESS [Moscow: OLMA-PRESS]. 2006; $830 \mathrm{p}$.

2. Vinokurov VA. Professional'nyj stress u vrachej [ Professional stress among doctors]. Vestnik MAPO [Vestnik MAPO]. 2010; 8-9: 104-105.

3. Vodopianova NE, Starchenkova ES. Sindrom vygoranya: diagnostika i profilaktika [Burnout syndrome: diagnostics and prevention]. Sankt-Peterburg: Piter [St Petersburg: Piter]. 2008; 56 p.

4. Boyko VV. Sindrom "emocional'nogo vygoraniya» v profesional'nom obshenii [Syndrome of «emotional burnout» in professional communication]. Sankt-Peterburg: Piter [St Petersburg: Piter]. 2004; 105 p.

5. Subaev MN, Setko NP. Osobennosti professional'nogo stressa u detskih vracheiy stomatologov v usloviyah proizvodstvennoij sredy [Characteristics of professional stress among child dentists in the working environment]. Sovremennye problemy nauki i obrazovaniya [Modern problems science and education]. 2015; 1-1: 1288.

6. Larentseva LI, Rvacheva EA. Professional'nyij stress i sindrom emocional'nogo vygoraniya vrachei-stomatologov na detskom ambylatornom prieme [Professional stress and syndrome of emotional burnout among dentists conducting outpatient treatment of children]. Rossiiskii stomatologicheskii zhurnal [Rossiiskii Stomatological Jurnal]. 2010; 1: 36-37.

7. Kotova EV. Profilaktika sindroma emozional'nogo vygoraniya: ychebnoe posobie [Burnout syndrome prevention: training manual]. Krasnoyarsk: Krasnoyarskii gosudarstvennii pedagogicheskii universitet imeni VP Astafeva [Krasnoyarsk: Krasnoyarsk State Pedagogical University named after VP Astafieva]. 2013; 76 p.

8. Lozinskaya El, Lutova NB. Sistemnyi index sindroma peregoraniya (na osnove testa $\mathrm{MBI}$ ): metodicheskie rekomendazii [System index of burnout syndrome (based on MBI test): methodological recommendations]. Natsional'niy meditsinskiy issledovatel'skiy tsentr psikhiatrii i nevrologii imeni VM Bekhtereva [National Medical Research Center for Psychiatry and Neurology VM Bekhtereva]. 2007; 103 p.

9. Maslach Ch, Cooper L. Mnogomernaya teoriya vygoraniya; Teoriya organizacionnogo stressa. [A multidimensional Theory of Burnout; Theories of Organizational Strees Cary]. Oxford Univercity press. 1998; 66-85.

10. Yudina NA. Obosnovanie patogeneticheskih mehanizmov vzaimosvyazi stomatologicheskih i obshchih zabolevanij [The rationale for pathogenic mechanisms of relationship between dental and general diseases]. Stomatologicheskii Zhurnal [Stomatological Jurnal]. 2007; 2: 16-19. 